\title{
Comparative Assessment of Performances of Vanaraja, Kamrupa and Desi Chicken Reared by Tribal Community of Lower Brahmaputra Valley Zone of Assam
}

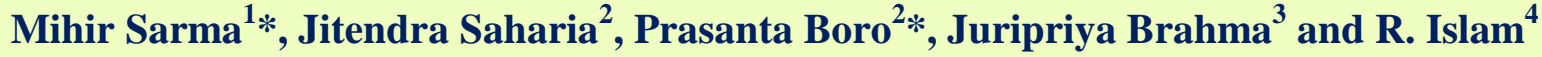 \\ ${ }^{1}$ Poultry Science, ${ }^{2}$ Livestock Production Management, ${ }^{3}$ Veterinary Clinical Medicine, \\ Livestock Research Station, Assam Agricultural University, Mondira, Kamrup, Assam, India \\ ${ }^{4}$ Deptt. of AHD, BN College of Agriculture, AAU, Biswanath Chariali, India \\ *Corresponding author
}

K e y w o r d s
Vanaraja, Kamrupa,
Desi chicken, Body
weight, Mortality,
fertility,
Hatchability
Article Info
$\begin{aligned} & \text { Accepted: } \\ & \text { 20 July } 2020 \\ & \text { Available Online: } \\ & \text { 10 August } 2020\end{aligned}$

\section{A B S T R A C T}

A study was undertaken to assess different productive and reproductive performances of Desi, Kamrupa and Vanaraja chicken under traditional system amongst tribal community of Lower Brahmaputra Valley Zone of Assam. Information on mean body weight at various ages groups, age at first egg, annual egg production, mortality rate, fertility and hatchability were obtained from farmers under the study. Significant $(\mathrm{P} \leq 0.05)$ differences were observed amongst the three breeds of chicken in terms of body weight, egg production and egg weight. The age at first egg was significantly $(\mathrm{P} \leq 0.05)$ higher in Desi chicken compared to Vanaraja and Kamrupa. But, no significant $(\mathrm{P} \leq 0.05)$ differences were found among all three groups of birds in terms of fertility, hatchability and mortality from $31^{\text {st }}-52^{\text {nd }}$ weeks of age except at the early age group. These evaluated performances of birds will help farmers to rear the right choice of chicken for their livelihood and also for sustainable backyard chicken farming in their locality.

\section{Introduction}

Rearing of Desi chickens under backyard system is a common phenomenon among the resource poor and underprivileged families in rural India, particularly among the tribal masses. Backyard poultry is a manageable and encouraging enterprise to improve the socio-economic and nutritional status of rural people especially landless and poor families with low initial investment and high economic return (Chakrabarti et al., 2014) as well as it has been given more emphasis for improving rural livelihood (Singh et al., 2018). These birds support them substantially for their livelihood and nutritional security. 
They produce meat and egg, which are the only sources of high quality animal protein among the villagers. Moreover, indigenous chickens are hardy, resistant to most of the common avian diseases, require almost no inputs and adapt well in harsh climatic condition. However, their production potential is much lower due to inferior genetic makeup. Further, the consumers prefer to purchase local egg and meat than commercial broilers and eggs. Local eggs and meat always fetches a premium price over the commercial counterparts. Hence, there is a huge gap between demand and supply of local poultry egg and meat among consumers. Keeping this point in mind, different multicoloured improved birds like Vanaraja, Gramapriya, Kamrupa etc. have been developed by different ICAR research stations, SAUs', private agencies etc. in India. These multicoloured birds perform much better even up to three times in terms of egg and meat under similar backyard condition. Under such circumstance, evaluation of such improved chicken under traditional field condition is the need of the hour to recommend farmers better birds under agroclimatic condition of Assam for sustainable economic improvement in rural farmers. There is scanty of information on production and productivity of Kamrupa and Vanaraja birds in Lower Brahmaputra Valley Zone of Assam. Hence, the present study was undertaken to know various productive and reproductive performances of these birds i.e Vanraja, Kamrupa and Desi birds under traditional system amongst tribal community of Lower Brahmaputra Valley Zone of Assam.

\section{Materials and Methods}

\section{Study area}

The study was carried out during the period from December, 2018 to November, 2019 in the tribal dominated areas of Lower Brahmaputra Valley Zone of Assam.

\section{Selection and sampling}

A total of 150 farmers were selected randomly from 15 selected villages, 10 farmers from each village for the study under the Tribal Sub-plant Project. Day old chicks numbering ten each of Vanaraja and Kamrupa were supplied to each farmer, selected on the basis of their experience in keeping a minimum 10-15 numbers of Desi chicken in their backyard. The Vanaraja and Kamrupa chicks were brooded under hover brooder up to 21days of age. During the said period, they were provided with ad libitum broiler pre-starter crumbs and clean potable drinking water. As per standard vaccination schedule, the chicks were vaccinated against Ranikhet and Gumboro diseases. The chicks were let loose during day time after proper brooding and were given supplemental feeding for a week until they were able to feed through natural feed resources.

\section{Data collection}

The data on body weights at hatch, 4, 8, 20, 40 and 52 weeks of age, age at first egg, egg weights at 32, 40 and 52 weeks of age, egg production up to $32,40,52$ and 72 weeks of age were recorded for the study. Mortality rate was recorded at 0 to 5,6 to 30 and 31 to 52 weeks of age.

Fertility and hatchability were studied using 500 numbers of eggs and 250 numbers from each variety of Vanaraja and Kamrupa, respectively. The eggs were collected within a period of one week from different stocks and were set in incubator. The fertility was tested on $7^{\text {th }}$ day of incubation by electric bulb and infertile eggs were removed from the incubator. Hatchability rate on TES and FES was calculated after 21 days of incubation period. 


\section{Statistical analysis}

The data so collected were tabulated and analyzed by using SPSS version 17.0 as per standard statistical methods (Snedecor and Cochran, 1994) and expressed in mean \pm SE. Duncan Multiple Range test of SPSS was performed for mean statistical significant difference.

\section{Results and Discussion}

Productive and reproductive performance of Vanaraja, Kamrupa and Desi chicken are tabulated in Table 1. Weight of Vanarja, Kamrupa and Desi chicks at hatch are $36.12 \pm 0.34, \quad 30.21 \pm 0.40$ and $24.27 \pm 0.51$, respectively. At $52^{\text {nd }}$ week of age, weight of Vanarja, Kamrupa and Desi birds are $3490.77 \pm 11.24, \quad 1957.34 \pm 9.71$ and $1408.35 \pm 8.12$, respectively. Weight of the above birds at $4^{\text {th }}, 20^{\text {th }}, 40^{\text {th }}$ and $52^{\text {nd }}$ weeks of age are presented in Table 1 .

Age at first egg in Vanraja, Kamrupa and Desi birds are $186.51 \pm 1.32,189.20 \pm 1.08$ and $197.30 \pm 1.02$, respectively (Table 1).

Numbers of eggs produced by Vanraja, Kamrupa and Desi birds at $32^{\text {nd }}$ weeks of age are $33.23 \pm 0.12,21.98 \pm 0.06$ and $11.23 \pm 0.04$, respectively and at $72^{\text {nd }}$ weeks of eggs are $162.02 \pm 1.02,140.50 \pm 0.80$ and $76.31 \pm 0.70$, respectively (Table 1).

Egg weight at $32^{\text {nd }}$ weeks of age of the birds under study is $47.82 \pm 0.22,38.40 \pm 2.30$ and $27.85 \pm 0.04$, respectively. Weight of the eggs produced by the birds at $72^{\text {nd }}$ weeks of age are $61.24 \pm 1.08, \quad 48.23 \pm 1.31$ and $41.14 \pm 1.03$, respectively (Table 1).

Higher mortality rates were observed in the above mentioned improved varieties during early part of their life (0-30th weeks of age) whereas lower mortality rate at later part of life (31-52 ${ }^{\text {nd }}$ weeks of age). No significant $(\mathrm{P} \leq 0.05)$ difference among the three groups of birds were noticed in terms of fertility and hatchability (Table 1).

\section{Body weights}

The data on mean body weights showed significant $(\mathrm{P}<0.05) \quad$ difference amongst Vanaraja, Kamrupa and Desi birds, at similar ages (Table 1). The mean body weights were significantly $(\mathrm{P}<0.05)$ higher in Vanaraja followed by Kamrupa and Desi in similar ages. The higher mean body weights recorded in Vanaraja and Kamrupa birds than Desi chicken might be due to superior germplasm utilized in the development of Vanaraja and Kamrupa. Islam et al., (2014) also reported similar mean body weights in case of Vanaraja and indigenous chicken in backyard system of rearing. Kalita et al., (2016) also observed similar body weight trends in Kamrupa with ages under similar condition. Daida et al., (2013) reported much lower body weight in Vanaraja at 20 weeks of age. However, Bharali et al., (2020) reported comparatively higher that body weight of Vanaraja birds at 40th week of age (3080.55 \pm 143.22 grams). The differences in body weights within same germplasm might be due to different managemental condition, supplemental feeding etc.

\section{Age at first egg production}

The mean age at first egg recorded in Vanaraja (186.51 \pm 1.32 days), Kamrupa (189.20 \pm 1.08 days) birds were significantly $(\mathrm{P} \leq 0.05)$ lower than Desi $(197.30 \pm 1.02$ days $)$ bird (Table 1). The significant difference of mean age at first egg among Desi, Vanaraja and Kamrupa might be due to differences in the genetic constituent. The present findings agreed with the results of several workers (Islam et al., 2014; Sarma et al., 2018 and Choudhary et al., 2019) in case of Vanaraja. 
The age at first egg in Kamrupa chicken observed in the present study was almost similar with Kalita et al., (2016). Deka et al., (2014) also recorded lower mean age at first egg in Vanaraja (178.13 \pm 0.79 days) and indigenous chicken (191.25 \pm 1.46 days) under backyard system. Besides, Bharali et al., (2020), Kumar et al., (2018), Sree et al., (2017) and Saikia et al., (2017) reported lower age of Vanraja hen at first egg laying as $162.55 \pm 11.43$ days, 179.3 days, 152 days and $181.05 \pm 1.52$, respectively.

Table.1 Productive and reproductive performance of Vanaraja, Kamrupa and Desi chicken

\begin{tabular}{|c|c|c|c|}
\hline Parameters & Vanaraja & Kamrupa & Desi \\
\hline \multicolumn{4}{|c|}{ Body weights (g) at } \\
\hline Hatch weight & $36.12 \pm 0.34^{\mathrm{a}}$ & $30.21 \pm 0.40^{b}$ & $24.27 \pm 0.51^{\mathrm{c}}$ \\
\hline $4^{\text {th }}$ week & $539.12 \pm 23.17^{\mathrm{a}}$ & $220.61 \pm 11.10^{b}$ & $164.29 \pm 5.18^{c}$ \\
\hline $8^{\text {th }}$ week & $756.34 \pm 5.42^{a}$ & $502.12 \pm 3.20^{b}$ & $365.13 \pm 2.64^{c}$ \\
\hline $20^{\text {th }}$ week & $1690.27 \pm 11.32^{\mathrm{a}}$ & $1320.34 \pm 9.34^{b}$ & $778.13 \pm 4.21^{\mathrm{c}}$ \\
\hline $40^{\text {th }}$ week & $2958.52 \pm 12.18^{\mathrm{a}}$ & $1850.20 \pm 10.30^{b}$ & $1240.41 \pm 8.21^{\mathrm{c}}$ \\
\hline $52^{\text {nd }}$ week & $3490.77 \pm 11.24^{\mathrm{a}}$ & $1957.34 \pm 9.71^{\mathrm{b}}$ & $1408.35 \pm 8.12^{c}$ \\
\hline Age at first egg (days) & $186.51 \pm 1.32^{a}$ & $189.20 \pm 1.08^{a}$ & $197.30 \pm 1.02^{b}$ \\
\hline \multicolumn{4}{|c|}{ Egg production numbers up to } \\
\hline $32^{\text {nd }}$ week & $33.23 \pm 0.12^{a}$ & $21.98 \pm 0.06^{b}$ & $11.23 \pm 0.04^{\mathrm{c}}$ \\
\hline $40^{\text {th }}$ week & $52.07 \pm 0.31^{\mathrm{a}}$ & $41.34 \pm 0.32^{b}$ & $25.62 \pm 0.16^{\mathrm{c}}$ \\
\hline $52^{\text {nd }}$ week & $87.28 \pm 1.01^{\mathrm{a}}$ & $80.40 \pm 0.62^{b}$ & $41.47 \pm 0.53^{\mathrm{c}}$ \\
\hline 72 week & $162.02 \pm 1.02^{\mathrm{a}}$ & $140.50 \pm 0.80^{\mathrm{b}}$ & $76.31 \pm 0.70^{c}$ \\
\hline \multicolumn{4}{|c|}{ Egg weight (g) } \\
\hline $32^{\text {nd }}$ week & $47.82 \pm 0.22^{\mathrm{a}}$ & $38.40 \pm 2.30^{b}$ & $27.85 \pm 0.04^{c}$ \\
\hline $40^{\text {th }}$ week & $53.97 \pm 0.24^{\mathrm{a}}$ & $41.50 \pm 0.21^{\mathrm{b}}$ & $31.08 \pm 0.08^{\mathrm{c}}$ \\
\hline $52^{\text {nd }}$ week & $57.80 \pm 0.27^{\mathrm{a}}$ & $43.60 \pm 0.10^{b}$ & $35.98 \pm 0.14^{\mathrm{c}}$ \\
\hline $72^{\text {nd }}$ week & $61.24 \pm 1.08^{\mathrm{a}}$ & $48.23 \pm 1.31^{\mathrm{b}}$ & $41.14 \pm 1.03^{c}$ \\
\hline \multicolumn{4}{|c|}{ Mortality (\%) } \\
\hline $0-5^{\text {th }}$ week & $11.33 \pm 1.42^{\mathrm{a}}$ & $7.85 \pm 1.16^{b}$ & $8.04 \pm 0.86^{b}$ \\
\hline $6-30^{\text {th }}$ week & $3.24 \pm 0.23^{\mathrm{a}}$ & $2.04 \pm 0.43^{b}$ & $1.84 \pm 0.33^{b}$ \\
\hline $31-52^{\text {nd }}$ week & $1.08 \pm 0.04^{\mathrm{a}}$ & $1.21 \pm 0.11^{\mathrm{a}}$ & $1.04 \pm 0.23^{\mathrm{a}}$ \\
\hline Fertility (\%) & $91.21 \pm 6.43^{\mathrm{a}}$ & $90.71 \pm 5.41^{\mathrm{a}}$ & $90.40 \pm 4.97^{\mathrm{a}}$ \\
\hline Hatchability on TES (\%) & $89.13 \pm 4.12^{\mathrm{a}}$ & $88.53 \pm 4.20^{\mathrm{a}}$ & $88.32 \pm 2.75^{\mathrm{a}}$ \\
\hline Hatchability on FES (\%) & $92.16 \pm 1.32^{\mathrm{a}}$ & $91.43 \pm 1.24^{\mathrm{a}}$ & $91.16 \pm 2.12^{\mathrm{a}}$ \\
\hline
\end{tabular}

Means bearing similar superscripts in a row do not differ significantly.

\section{Egg production}

The mean egg production differed significantly $\quad(\mathrm{P} \leq 0.05)$ amongst Desi, Vanaraja and Kamrupa chicken, which might be due to differences in the genetic makeup of birds. The mean egg production was significantly higher in Vanaraja followed by
Kamrupa and Desi chicken at different ages under backyard system. The egg production up to $52^{\text {nd }}$ week of age in Vanaraja reported in the present study was in accordance with the finding of Choudhary et al., (2019). Similarly, mean egg production in Desi chicken at 72 weeks of age was also corroborated the finding of Sarma et al., 
(2018). However, lower corresponding value of egg production (149.47 4.46 numbers) in Vanaraja up to 72 weeks of age was recorded by Niranjan et al., (2008). Kalita et al., (2016) recorded much lower annual egg production in Kamrupa than the present findings, which might be due to availability of feed resources in the study areas.

\section{Egg weight}

The data on mean egg weight also showed significant $(\mathrm{P} \leq 0.05)$ difference amongst Desi, Vanaraja and Kamrupa birds (Table 1). The weight of Vanaraja, Kamrupa and Desi eggs were $57.80 \pm 0.27,43.60 \pm 0.10$ and $35.98 \pm 0.14$ respectively at $52^{\text {nd }}$ week of age. The present findings were in accordance with the findings of Islam et al., (2014) in Vanaraja and indigenous chicken and Niranjan et al., (2008) in Vanaraja chicken. In contrast to the present findings, Deka et al., (2014) reported much lower egg weight in Vanaraja (51.08 \pm 0.36$)$ and $59.06 \pm 0.42 \mathrm{~g}$ at 40 and 72 weeks of age respectively and it was $36.12 \pm$ 0.62 and $41.07 \pm 0.48 \mathrm{~g}$ at 40 and 72 weeks of age respectively in indigenous chicken under backyard system These variation in egg weight might be due to supplemental feeding, genetic make-up and differences in management. Higher egg weight at 40th week $(57.06 \mathrm{~g})$ and $72 \mathrm{nd}$ week $(62.35 \mathrm{~g})$ was recorded by Niranjan et al., (2008b) in Vanaraja chicken. The mean egg weight observed in Kamrupa chicken in the present study was much lower than the weight recorded by Kalita et al., (2016) at 40 weeks of age.

\section{Mortality}

The significantly $(\mathrm{P} \leq 0.05)$ higher mortality rates were recorded in the above mentioned improved varieties than the Desi chicks during early part of their (0-30th weeks of age). The lower mortality rate in Desi chicks than the improved chicks might be due to more hardiness and proper natural brooding by their broody mother whereas the higher mortality rate in improved chicks, Vanraja and Kamrupa might be due to faulty brooding arrangements like cold shock and huddling The mortality at later part of life $\left(31-52^{\text {nd }}\right.$ weeks of age) was mostly due to predators in all the cases and no significant $(\mathrm{P} \leq 0.05)$ difference were noticed among three groups (Table 1). The present findings were well in agreement with the findings of Bhattacharya et al., (2005), Niranjan and Singh (2005) and Islam et al., (2014) who had reported the mortality rate in the range of $0-15$ percent for birds reared under similar conditions. But, Zuyie et al., (2009) reported much lower mortality in Vanaraja chicken. Also, much lower mortality rate was reported by Kalita et al., (2016) in Kamrupa than the present findings up to $40^{\text {th }}$ week of age.

\section{Fertility and Hatchability}

While recording, per cent fertility and hatchability, there was no significant $(\mathrm{P} \leq 0.05)$ difference among the three groups of birds (Table 1). The present findings were in accordance with the findings of Islam et al., (2014). Kalita et al., (2012) and Deka et al., (2017) also reported higher rate of hatchability as as 81-100\%) and 89.07 \pm 4.11 , respectively in indigenous chicken of Assam. In contrast to the present findings, Roy et al., (2018) reported lower hatchability of fertile eggs in Vanaraja birds (85.22\%) and indigenous birds $(86.98 \%)$. Besides, Kumar et al., (2005) reported lower hatchability as 72.6 per cent in Vanaraja birds under traditional system of rearing in Manipur. Kalita et al., (2016) also reported similar fertility and hatchability in Kamrupa in Assam.

From the present study, it may be concluded that Vanaraja and Kamrupa birds are well suited and adapted to our agro-climatic 
condition of Assam, especially Lower Brahmaputra Valley Zone of Assam and can be reared by farmers in small scale backyard system along with Desi birds. Thereby, such initiatives can usher livelihood, nutritional and food security to the farmers as well as sustainable production.

\section{Acknowledgement}

The authors are thankful to the Directorate of Research, (Vety.), AAU, Khanapara, Guwahati-22 for their necessary continuous support and guidance to carry out the research work. The authors are also thankful to the farmers for providing various data for the study.

\section{References}

Bhattacharya, M., Buragohain, R., Ahmed, F. A., Pathak, P. K. and Ghosh, M. K. 2005. Laying performance of Vanaraja birds in high altitude areas of Arunachal Pradesh under backyard system of rearing. Proceedings of XXIII Annual Conference and National Symposium of Indian Poultry Science Association. 2-4 February, Hyderabad, India, 2: 369 (Abstr.).

Bharali, D., Borah, D., Rajbonshi, P. and Dutta, L. J. 2020. Study on Adaptability, Productive Performance and Constraints of Vanaraja Birds in Backyard System of Rearing at Udalguri District of Assam, India. International Journal of Current Microbiology and Applied Sciences, 9 (3): 986-99.

Chakraborti, A., Dey, A. and Barari, S.K. 2014. Backyard Poultry farming-a source of better livelihood for rural farmers. Krishisewa.

http://www.krishisewa.com/article/livestoc k/410-backyard farming.html/12.04.2019.

Choudhary, R.K., Roy, M.K. and Sohane, R.K. 2019. Livelihood upliftment of tribal farmers through backyard poultry farming intervention in Kishanganj district of
Bihar. Journal of AgriSearch, 6: 90-92.

Chutia, H. (2010). Study on some productive and reproductive traits of indigenous chicken of Dhemaji district of Assam. M. V. Sc. Thesis, Assam Agricultural University, Khanapara, Guwahati, Assam, India.

Daida K, Preetham VC, Reddy VR and Rao STV. 2013. Growth performance and liveability of Rajasree birds on farm and field level. In Compendium 2: XXX IPSACON, National Symposium on Poultry Production: Feed, Food and Environmental Safety, 22-23 November, 2013, CARI, Izatnagar, Bareilly, India. pp. 218.

Deka, P., Sarma, M., Nath, P. J., Borgohain, R., Mahanta, J. D., Deka, B. and Phukon, M 2014. Production performance of Vanaraja bird under traditional system of rearing in Assam. International Journal of Livestock Research, 4(2): 81-85.

Deka, B.C., Deka, C.K., Islam, R., Hussain, M and Paul, A. 2017. Production performance of improved backyard rural poultry in NICRA village of Dhubri district of Assam. International Journal of Chemical Studies, 5(3): 802-804.

Islam, R., Kalita, N. and Nath, P. 2014. Comparative performance of Vanaraja and Indigenous chicken under backyard system of rearing. Journal of Poultry Science and Technology, 2 (1): 22-25

Kalita, N., Islam, R., Pathak, N. and Chutia, H. 2012. Hatchability and mortality of indigenous chicken of Assam. Indian Veterinary Journal, 89: 35-36.

Kalita N, Pathak N and Ahmed M. 2016. 'Kamrupa'- A new dual chicken variety for farmers of Assam and North- East India. Indian Journal of Animal Sciences, 86: 686-690.

Kumar, Sanjay., Kumar Sushil and Kumar , A.K. 2018. Comparative Evaluation of Grampriya and Vanraja with Local Desi Bird in Dumka District Int.J.Curr.Microbiol.App.Sci Special Issue-7: 3700-3705.

Kumar, S., Ngachan, S. V., Sunder, G. S. and 
Devi, N. K. 2005. Production performance of Vanaraja birds under traditional system of rearing in Manipur. In: Proc. of 23rd Annual Conf. and National Symp. IPSACON, held on Feb, 2-4; Hyderabad, India, 2: 382

Kumaresan, A., Bujarbaruah, K. M., Pathak, K. A., Chhetri, B., Ahmed, S. K. and Haunshi, S. 2008. Analysis of a village chicken production system and performance of improved dual purpose chickens under a subtropical hill agroecosystem in India. Tropical Animal Health and Production, 40: 395-402.

Niranjan, M., Sharma, R. P., Rajkumar, U., Reddy, B. L. N., Chatterjee, R. N. and Bhattacharya, T. K. 2008. Comparative evaluation of production performance in improved chicken varieties for backyard farming. International Journal of Poultry Science, 7: 1128- 1131.

Niranjan, M. and Singh, N. P. 2005. Performance of Gramapriya under intensive and free- range conditions of Tripura. Proceedings of XXIII Annual Conference and National Symposium of Indian Poultry Science Association. 2-4 February, Hyderabad, India, 2: 366 (Abstr.)

Roy, Amitava., Datta Sanjoy., Roy, Partha Sarathi., Biswas, Sukanta and Mishra, Sidharth Prasad. 2018. Comparative Assessment of Production and Hatchability Performance of Vanaraja, Rhode Island Red and Indigenous Poultry Birds under Backyard Rearing System at West Bengal. International Journal of Livestock
Research. 7(8): 296-303.

Saikia, A.K., Gogoi, G and Neog, M. 2017. Productive and Reproductive Performance of Vanaraja Birds Reared by Tribal Community of Dhemaji District of Assam. J Krishi Vigyan 6(1): 162-165.

Sarma, M., Islam, R., Borah, M.K., Sharma, P., Mahanta, J.D., Kalita, N. and Bhattacharyya, B.N. 2018. Comparative performance of Vanaraja, Srinidhi and Desi chicken under traditional system among tribal community of Assam. Indian Journal of Animal Research, 52(10):15181520.

Snedecor, G. W. and Cochran, W. G. 1994. Statistical Methods. 6th Edn, Oxford and IBH Publishing Co. Calcutta.

Singh, Simran., Chakraborty, D., Altaf, Sahil., Taggar, R.K., Kumar, N and Kumar, D. 2018. Backyard poultry system: A boon to rural livelihood. International Journal of Fauna and Biological Studies, 5(1): 231236.

Sree, E. K., Nirmala, T. V and Reddy, R.V.S.K. 2017. Comparative performance of different varieties of chicken under backyard system of rearing in tribal and rural areas of west Godavari District, A.P. International Journal of Science, Environment and Technology, 6(2):1100 1104.

Zuyie, R., Sharma, V. B., Bujarbaruah, K. M. and Vidyarthi, V. K. 2009. Performance of Vanaraja birds under intensive system of rearing at different altitude in Nagaland. Indian Journal of Poultry Science, 44 (3): 411-413.

\section{How to cite this article:}

Mihir Sarma, Jitendra Saharia, Prasanta Boro, Juripriya Brahma and Islam, R. 2020. Comparative Assessment of Performances of Vanaraja, Kamrupa and Desi Chicken Reared by Tribal Community of Lower Brahmaputra Valley Zone of Assam. Int.J.Curr.Microbiol.App.Sci. 9(08): 2422-2428. doi: https://doi.org/10.20546/ijcmas.2020.908.277 